\title{
THE RELEVANCE OF CONFUCIAN VALUES TO LEADERSHIP COMMUNICATION
}

\author{
Joyce Cheah Lynn-Sze, Norhafezah Yusof \& Mohd Khairie Ahmad \\ Universiti Utara Malaysia
}

\begin{abstract}
Research on leadership communication is still an active area of inquiry as can be seen from the growing number of studies employing different perspectives to enhance the contributions of the field in its own right. From the intercultural communication perspective, every culture provides a particular view of leadership communication because each culture has tended to look at certain cultural conceptual artifacts differently. For example, in Asia, the studies on leadership communication tended to focus on Japanese and Korean and there are only a few studies which have used other cultural notions like the ones carried out in Malaysia. Among the challenges faced by the leaders in Malaysia are the ways to remain relevant in light of rapid changes in the country. The priority is, therefore, to be able sustain the impressive achievements made thus far in the rather challenging context of a multi-racial and multireligious society, especially the need to understand the cultural thinking of the Chinese community after the recent General Election (GE13). This article discusses the Chinese and Western leadership cultures and the roles of Confucian values in leadership communication in East Asia. On the basis of insights gained, a model has been proposed to guide the development of subsequent leadership communication studies, particularly that which involves the Chinese community in Malaysia.
\end{abstract}

Keywords: Leadership communication; values; intercultural communication; Confucianism; Chinese community 


\title{
PERKAITAN NILAI CONFUCIUS KE ATAS KOMUNIKASI KEPIMPINAN
}

\begin{abstract}
Abstrak
Penyelidikan tentang komunikasi kepimpinan masih berterusan sehingga ke hari ini walaupun telah banyak kajian dilaksanakan dari pelbagai perspektif. Berdasarkan perspektif komunikasi antara budaya, setiap budaya memerlukan aspek komunikasi kepimpinan yang berbeza kerana setiap budaya adalah unik. Malah di negara Asia, kajian tentang komunikasi kepimpinan cenderung memfokuskan kepada budaya Jepun dan Korea tetapi masih kurang kajian boleh didapati dalam konteks budaya lain seperti di Malaysia. Cabaran-cabaran yang dihadapi oleh pemimpin Malaysia adalah supaya sentiasa releven terhadap perubahan negara. Oleh itu, keutamaannya adalah dapat mengekalkan pencapaian yang mengagumkan dalam konteks yang agak mencabar, iaitu dalam masyarakat yang berbilang kaum dan agama, terutamanya keperluan dalam memahami pemikiran budaya masyarakat Cina selepas Pilihan Raya Umum (PRU13) baru-baru ini. Artikel ini membincangkan tentang budaya kepimpinan Cina dan Barat dan peranan nilai-nilai tradisi Confucianisme dalam komunikasi kepimpinan di Asia Timur. Pandangan ini boleh menyumbang kepada model yang dapat memberi panduan kepada pembangunan kajian komunikasi kepimpinan yang selanjutnya, khususnya dalam perspektif masyarakat Cina di Malaysia.
\end{abstract}

Kata kunci: komunikasi kepimpinan; nilai; komunikasi antara budaya; Confucianisme; masyarakat Cina

\section{INTRODUCTION}

The development of a country is often related to the leader in power. Nevertheless, it is imperative to state that leadership communication can inspire the nation towards realizing the vision of their leader (Willburn, Hackman \& Criswell, 2008). In discussing the concept of communication, culture cannot be separated from this topic since the practice of one's culture is evident when he or she communicates (Merkin, 2009). The focus on Western leadership styles is perhaps not sufficient in today's globalized world where intercultural communication is susceptible to occur. This is true especially for leaders who are leading in multicultural countries as they need to adapt to different leadership styles in an attempt to implement their tasks effectively (Wang, 2011). 
Chinese society in Malaysia is not provided with Confucian education directly. However, their lifestyle is somewhat influenced by Confucian ideology (Low, 2013). This ideology has extensively affected the Chinese people's lifestyle until today. Malaysia is a multicultural and multiethnic country. Every ethnic group possesses its own identity and culture, and they live together in harmony (Storz, 1999). Therefore, intercultural communications occur pervasively among people of different races and ethnicities in Malaysia. Several papers have identified a possible converging of Western and Chinese leadership, such as in Japan and Korea (King \& Zhang, 2014). Such research, however, has not posited a possible convergence between the two leadership models in developing multicultural notions like the ones carried out in Malaysia.

Asian culture and Islamic values have always been central to the $4^{\text {th }}$ Prime Minister of Malaysia, Tun Dr. Mahathir's worldview and his commitment to changing the outlook, attitudes and habits of Malaysians by claiming that Asians have their own cultural and ideological practices that uphold the core values of shared values, collectivism and consensus. Therefore, Asian nations should continue to conduct day to day lives upholding these values (Zarina \& Faisal, 2010). The idea of blending Malay leadership style and Confucian values can stimulate extensive studies on new perceptions, especially in the aspect of Chinese culture and communication concept in Malaysia.

In view of traditional Chinese philosophy and thoughts, instead of merely focusing on the understanding of Confucian values, the study aims to bring up the idea of Confucian values in Malaysian leadership culture that facilitates an understanding of how leaders will lead this country effectively in the future. In the next part, this paper first discusses the Chinese and Western leadership culture towards leadership communication study. Then, the roles of Confucian traditional values in leadership communication are highlighted. Next, issues pertaining to intercultural communication in Malaysia are discussed. Finally, this paper attempts to propose a Confucian model to guide the development of subsequent leadership, communication studies, particularly that involves the Chinese community in Malaysia.

\section{THE CHINESE AND WESTERN LEADERSHIP CULTURE}

Although the Chinese culture and the Western culture have known each other's presence for the past century, little mutual penetration has occurred at the everyday level with many entrenched stereotypes and biases towards each other (King \& Zhang, 2014). While this is true in everyday and international interactions between the East and the West, it is also true in academic studies of leadership practices. Having been an arguably less developed country, China has since abandoned many of its socialist beliefs and increasingly adopted Western leadership principles while retaining many of its traditional Confucian-based principles (Han, 2013). Concurrent with the Chinese's adaptation to Western ideas, the Western has become aware of traditional Chinese leadership ideas too 
(de Man, 2011; Lang, Irby, \& Brown, 2012).

Leadership issues are people issues that reflect how people react to the plethora of challenges that arise and, in particular, how leaders react. How leaders react successfully has been examined by many researchers who have found that success is in part influenced by the leader's cultural background and also the cultural backgrounds of followers (Matveev \& Lvina, 2007; Cheng et al., 2013).

The study on Chinese leadership was initiated by Misumi (1985). Misumi is an influential Japanese scholar in the study of contemporary Chinese leadership. The study of Misumi was in line with the research of Ohio State (Fleishman, Harris \& Burtt, 1955) and the study of Michigan (Katz \& Kahn, 1952) that focused on the dimensions of tasks and relationship among individuals in leadership.

Subsequently, after the study of Misumi as the starting point (1985), a group of Chinese Social Science researchers began to develop Chinese leadership theory (Hui \& Tan, 1999). They discovered that performance and relationship model was relevant to a variety of Chinese government organizations (Wong, Wong, \& Li, 2007; Kim, 2011). However, interviews with the informants indicated that the patterns of performance and relationship were not enough to interpret leadership in the working culture of Chinese people. The Chinese researchers asserted that an effective leader needed a good moral (Ling, Chia \& Fang, 2000). Among the dimensions of morals are truthfulness and self-control. Thus, the Chinese leadership theory concentrates on the importance of performance and the maintenance of relationships with significant moral values combined.

In the aspect of leadership, bravery, charisma and discipline are the high quality characteristics of a Western leader. In contrast, Eastern leaders prioritize the qualities such as wisdom, patience, endurance, strength and tolerance. A Confucian leader can maintain the balance between the good and the bad, rather than can he make an effort to eliminate the bad and create the good. In Ling et. al (2000)'s study, versatility was one of the four main characteristics of a successful Chinese leader. This is different compared to Western leadership theory. Chinese society has the view that versatility is merely a talent and only intelligent people possess it. Besides, according to Chinese culture, this issue is quite impossible for a leader to get recognition from his versatile followers.

A good relationship of a leader is seen to have given him much potential to succeed. Besides, a leader is expected to be mature, confident, outspoken, elegant, and good at socializing with the outside world (Ling et al., 2000). These attributes are quite similar to Western leadership theory, but they are more complicated. Li and Moreira's study (2009) revealed that about $69.8 \%$ of their respondents answered the building of long-term relationship (guanxi), while almost $55.6 \%$ of their respondents answered focusing on the aspect of harmony. This result showed that long-term relationship and harmony were considered important among the Chinese.

According to Cheung and Chan (2008), the style of Chinese leadership is identified from the perspective of Confucianism. Identification is important to 
Chinese leadership and this is different compared to Western leadership. For example, hierarchy and centralization of power in Chinese leadership perhaps are effective in the context of Chinese society but these can be unproductive with respect to Western context (de Man, 2011). Besides, leadership practices such as negotiation with employees as well as appreciation and recognition awarded to them perhaps are not effective. In Confucian leadership style, the followers need to appreciate social harmony and maintain good relationships.

Furthermore, a leader needs to motivate his followers and if this does not happen, success is impossible to achieve (Wong \& Kong, 2014). According to Confucian principal, leadership communication should be based on humanity, politeness and generosity. The elements of humanity exist in respect, while politeness can be seen in goodness and sincerity. Generosity includes strength, patience and tolerance towards employees. If these values are practiced by a leader, this can result in a high level of trust. In addition to that, the leadership attributes that can be followed by the employees are enthusiasm and dedication. This is because leadership through example is imperative in improving employees' motivation (James \& Lahti, 2011). Dedication in the followers will not be developed if a leader does not show any enthusiasm and responsibility in doing his tasks.

Cheng, et al. (2013) argued that cultural values should be exercised continuously and they have a significant influence on the improvement of a leader and the society. Besides, according to Scarborough (1998), even though the values of a leader are influenced by the society and pressure, the values are still in line with his cultural mainstream values and his behavior. For instance, leadership practices as well as the practices of the society in East Asia reflect the cultural values that are originated from Confucianism.

Despite this, Chinese philosophies and Western thinking have different ideas about leadership (de Man, 2011). With regard to contextual thinking and relationship in Chinese philosophies, a leader is part of social reality. Chinese philosophies emphasize the relationship between a leader and his followers in terms of their mutual role for influencing and not for forming an interaction between autonomous individuals (Han, 2013). In contrast, Western leadership tends to prioritize reward, vision, motivation, intellectual stimulation and tolerance for individuals (King \& Zhang, 2014).

Leadership research published in the last two decades directly or indirectly reported the relevance of Chinese humanistic concepts to Western management theories (Lakey, 2007; Gao, Arnulf, \& Kristofferson, 2011; Connor, Min, \& Iyengar, 2013). The idea of blending tradition with modernity has been discussed quite extensively (King \& Zhang, 2014). If traditional and modern leadership principles are converging, there should be evidence in each culture of crosscultural assumption or assimilation from the other culture. That is, a traditional principle from the Chinese humanistic principle becomes a modern principle in the other culture. However, the extent of such principles is limited by existing knowledge, that is, existing knowledge limits the extent of available principles 
that can be transferred cross-culturally (King \& Zhang, 2014). To what extend the Confucianism concept in the multicultural foundations would impact the society would be an interesting issue for intellectual discourse.

\section{THE ROLES OF CONFUCIAN VALUES ON LEADERSHIP COMMUNICATION IN EAST ASIA}

The influence of Confucianism in Asian countries has resulted in the Chinese community in East Asia sharing a culture that is based on Confucian ideology. Confucianism is a moral system, social, political and religious teaching based on the ancient Chinese tradition created by an early Chinese philosopher, Confucius and it was later developed by Mencius (Hershock \& Ames, 2006). The main values of Confucianism are ren (humaneness), yi (righteousness), $l i$ (propriety), zhi (knowledge), xin (integrity), zhong (loyalty), shu (generosity), and xiao (filial piety) (Thompson, 2010). These values represent nobleness that unites the Chinese people and the values are the essence of East Asian ideological and cultural values. Therefore, Confucian values have given a significant impact on communication practice in Asia (Cheung \& Chan, 2008).

Even though Confucian thinking has been around China for over 2500 years, Confucianism has not been the main cultural ideology and it has been discarded since 1911 (Wong \& Kong, 2014). In spite of this, Confucianism has become part of the Chinese gene which impacts on their attitudes and behaviors. Given that there are no clear boundaries between political, cultural and business life in China by Western standards, Confucian beliefs are deeply embedded in the Chinese business culture, especially in state-owned enterprises and large private companies. Even Chinese managers and employees working for foreign multinational companies still retain many Confucian values, though in a more subtle way.

Besides China, most Asian countries such as Japan, South Korea, Hong Kong, Taiwan, Singapore and Malaysia are also influenced by Confucian ideology. Lang, Irby, \& Brown (2012) claims that Chinese people in East Asian countries own a similar characteristic that is the practice of Confucian culture as their cultural element and heritage. Cultural values are the guidance for people's actions and reactions. On the other hand, a leader's behavior reflects the cultural values that are related to the behavior of the society. Even though today's generation is more individualistic compared to previous generation, the culture and social structure in Asian countries are still based on traditional values and this is different to Western perspective toward leadership communication (de Man, 2011).

Based on the study conducted by The Chinese Culture Connection (1987), the data obtained from 22 countries revealed that cultural values influenced the effectiveness of an organization, especially in Asian countries. The findings indicated that these values did not only distinguish the orientation between Western and Eastern cultures, but it was also discovered that this was closely 
related to the economic growth of a country. This shows that there is a significant relationship between culture and leadership communication. Therefore, the influence of Confucianism in East Asian countries is an issue that is recommended to be studied by communication scholars (Chen \& Chung, 1993; Lu, 2000).

Confucianism dominated the Chinese political ideology and provided archetypal images for Chinese communication behavior for over two thousand years (Lu, Xia \& Heisey, 2002). One reason that Confucianism has had such a profound impact is that Confucianism principles were used as the official philosophy during Dynasty Yi (1392-1910) and it was developed during 500 years of ruling. There were some schools specializing in teaching Confucianism by spiritual leaders. They also practiced Confucian principles and the most important Confucian element was 'obedience towards parents' (Farh \& Cheng, 2000). Nevertheless, Meiji government (1868-1911) in Japan had used Confucian principles in building a country with the Emperor as the highest power. Loyalty was stressed in Confucian elements because they viewed the relationship between an Emperor and his people as the relationship between a father and his son.

Korean culture is changing, but not drastically, as a result of technology and globalization (Merkin, 2009). Today, the young generation has slightly deviated from Confucian values that have so far guided their parents in their lives (Lang, Irby, \& Brown, 2012). However, Korean community still abides by traditional Confucian values compared to the Japanese and Chinese communities in China.

Confucian leadership is built based on morals and a leader who practices it can clearly be identified through his noble character (Sheh, 2010). A Confucian leader needs to have a high moral and this principle set as the main pillar of leadership (Sheh, 2010). If a leader of an organization does not exercise Ren concept, then the organization will not receive any confidence and trust from its followers. To obtain his people's trust, a Confucian leader should be trustworthy, that he can be trusted and is noble.

Besides, the study of Cheung and Chan (2008) found that the leaders in Hong Kong concentrated on social harmony. Among their leadership values were humanity, politeness, understanding, empathy and humbleness. These values are in line with Confucian leadership. Confucian leadership elements such as identification, trust, learning and moderation also could obviously be seen in the leaders. Therefore, it is clear that Confucian leadership plays an important role among the leaders in Hong Kong.

Li and Moreira's study (2009) revealed that Confucian influence took place in the lives of the Chinese people in Portugal. They still practiced the same Chinese lifestyle even though there were other Chinese people that immigrated to other countries and practiced a different culture as well as spoken a different language. The Chinese community that was influenced by Confucianism was familyoriented. Even though a good relationship was managed to be built with the local people, their family relationship was still close. The study also discovered 
that the Chinese organizations had employed the Portuguese in an attempt to integrate into the local culture and facilitate communication and treated their employees as their family and respected them.

In Singapore, Confucian values have played an important role in the Asian values argument. By appealing to Confucius, the government was able to create a certain amount of ideological coherence in its version of Asian values and to give it some academic respectability. Singapore's former prime minister, Lee Kuan Yew was actively trying to promote Confucianism elsewhere in Asia, particularly in China, where he has found an enthusiastic audience. Lee Kuan Yew claimed that he has always advocated Confucian values, demonstrating various paternalistic-authoritarian precepts among its ethnic Chinese majority society (Low \& Ang, 2012).

There were also some Western researchers that studied the attributes of Confucian culture and related them to leadership in East Asia (Lang, Irby, \& Brown, 2012). They investigated the aspect of Confucian values in influencing the communication pattern in an organization. The findings indicated that Confucian principles had influenced the interpersonal relationship in the organization.

However, cultural values change according to time. This is especially true in relation to the drastic changes among the communities in East Asia. Lu et al. (2002) argue that intellectual views on the effects of Confucianism in today's era are very different. In fact, Malaysia has experienced some social and economic transformation processes since its independence.

In achieving the vision a leader wishes to realize, leadership characteristics are important to understand (Cheng, 2011). A good leader is able to form a reasonable vision and at the same time he tries to convince his people his desire and ability to achieve the vision. This is for the purpose of making his followers have a good reason and are confident to realize the vision. Besides, a leader needs to show that he is capable of solving problems with respect to changes and other factors that can cause the achievement of the vision to fail. Therefore, according to Confucian ideology, leadership is an aspect that shapes and implements values in maintaining a vision to be achieved and taking actions to achieve the vision.

Generally, every country has its own uniqueness (Christopher \& Meyer, 2008). However, the arguments presented above prove that there are not so many differences in the practice of Confucian values among the Chinese people in East Asia. While Malaysia certainly does not represent all Asian cultures, the prominence the government of Malaysia has assumed in the Asian values debate makes its position worthy of examination.

\section{INTERCULTURAL COMMUNICATION IN MALAYSIA}

In Malaysia, even though a large portion of cultural dimension between the Malays and the Chinese are the same, there are still differences in terms of the level and priority of their respective values (Kennedy, 2002). For example, Malay people consider sincerity as the most important value, while the Chinese deem 
politeness as the most crucial value (Fontaine, Richardson \& Yeap, 2002). The studies regarding the cultures in Malaysia tended to exclude this phenomenon and they believed that the races in Malaysia are homogenous (Fontaine \& Richardson, 2003). There was a research conducted on diversity of values that it examined trust system that shaped the values and attitudes of the Malays and Chinese in the context of management culture in Malaysia (Storz, 1999). Nevertheless, it is not within this scene of paper to explain the difference in the values and attitudes dominated by the Chinese people towards the leaders in Malaysia.

For a country that possesses a dominant culture, the expectations pertaining to the communication between a leader and the community as well as the stereotypical predictions towards minority groups have long been in conflict. This occurs especially in the Chinese community (Lee, 2004). The Chinese people that comprise of a quarter of the population in Malaysia are not only influenced by their interaction with the Malays and other races, but also by the politics as well as their perception towards the government that is dominated by the Malays. However, it is discovered that local Chinese and foreign researchers focused more on the issue of social justice and equality in their studies. They did not highlight people's perception towards the vision designed by political leaders (Freedman, 2001; Mason, 2009; Lee, 2010). On the contrary, the research done by Malay researchers concentrated more on the economic monopoly by the Chinese people, and the problems and the rights of the Malays. There was lack of studies conducted on the feelings and perceptions of the Chinese (Mohd Rizal \& Sharifah Aluya, 2000; Chin, 2001).

Despite this, the study done by Storz (1999) revealed that Malays' lifestyle was closely related to complex values. This concept was considered to be similar to Confucian values in the lives of Chinese people. For example, this occurs with regard to inculcation of moral values and humane development. This similarity has some implication to the attitude and behavior that can reflect some particular aspects in the cultures in Malaysia (Low, 2013).

Malay leadership is a leadership style based on their cultural and religious values, and being predominantly Muslim, Malay leaders put into practice the Islamic values (Low, 2011). The leadership style of the Malays is very directive. Individuals are expected to obey the seniors and also to those who are at the top hierarchy in organizations. Besides, from the Islamic perspective, the people are encouraged to listen and obey the leader's commands or instructions as long as they are not against Islamic teachings. And one can say that Islam or Islamic values subscribe to paternalistic leadership and hence it is also applicable to Confucian leadership values (Cheng, et al., 2013). 


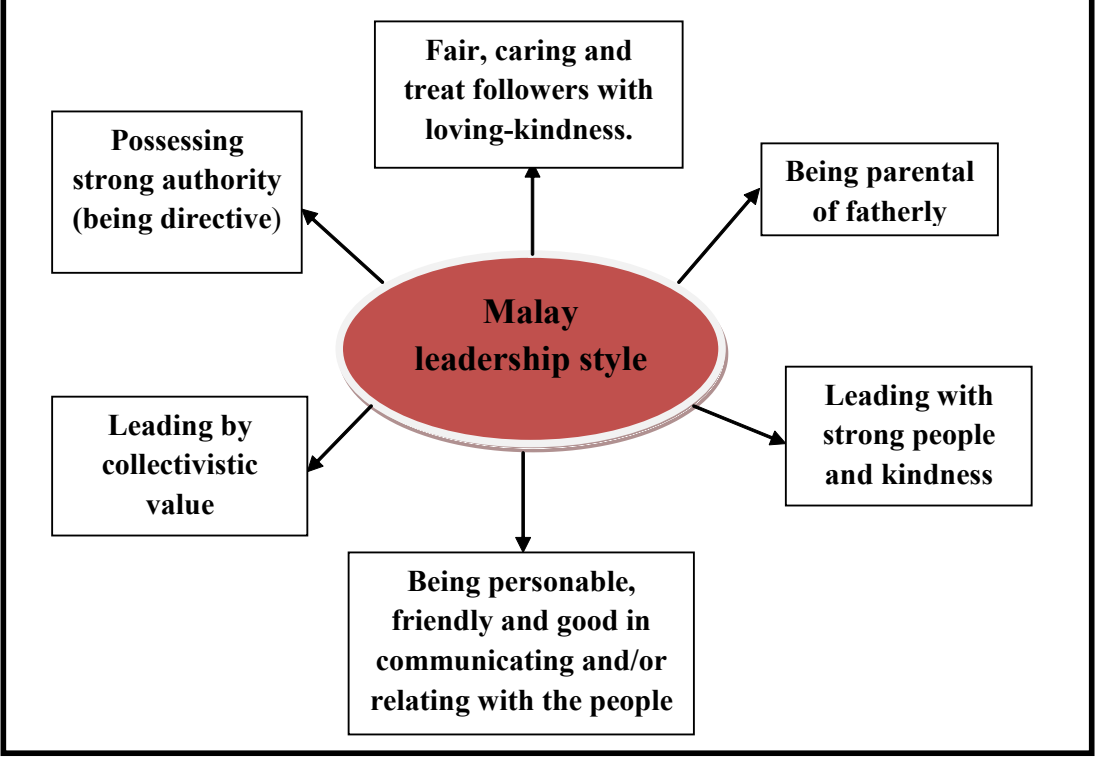

Figure 1: Key leadership style and ways of Malay leaders (Low, 2011).

Figure 1 captures the Malay leadership style and ways in Brunei (Low, 2011). Based on the research findings, the Malaysian leadership style of former Prime Ministers, Tun Dr Mahathir Mohammad and Tun Abdullah Ahmad Badawi also evaluated as practicing paternal-leadership (Low, 2008). Tun Dr. Mahathir showed that he cared for his people, provided for the Malaysian family, convincing them of the need to change their attitudes to help the country become more developed (Hamzah, 2003). While Tun Abdullah, commonly called as Pak Lah, is said to be "gentle", "Mr. Nice Guy" and hence is more approachable (Hamzah, 2003). However, a universal concept of leadership cannot mean that "one size fits all." Just as a multilingual communicator will use the language of the audience, a leader needs to choose the leadership style appropriate for the followers.

After reviewing the literature, it was determined that the research on Malay leadership are close to the concept of Confucian values (Low, 2011; Low, 2013). Both cultures also attempt to establish rapport, kindness and people-centered values. What is clear is that both concepts have had significant impacts toward the Malaysian society. However, it is believe that Malaysians of various ethnic groups have been acculturated or, at least, influenced by Confucian values (Lin, Ho, \& Lin, 2013; Han, 2013). While embracing the values of benevolence and humanistic, the leadership research were primarily focus on Confucianism-based organization value and achievement of economic benefits (Kim, 2011; Low, $\&$ Ali, 2012; Han, 2013). So far, however, there is no such research showing 
that such philosophy has been generally incorporated into Malaysian political leadership.

This scenario indirectly has limited the academic context that stresses the issue of communication between cultures in Malaysia. Anyway, viewing it from positive perspective, this indirectly can contribute to the comprehension and the building of multi-racial society that appreciate mutual understanding between one race and the other.

\section{CONCLUSION}

At the outset of this review, the researchers suggest that the topics and focus of previous research not only give certain impressions about similarities between the concepts of Confucianism and Malay leadership values even though both were from different cultures. One of the benefits and value of the paper lies in that it provides an interesting perspective plus a continuing discussion and further research on leadership and governance in Malaysia. In fact, the findings of this kind of study can support the political scenario in Malaysia that is gradually moving from racial-based politics to multi-racial politics. The issue suggested is the perception of a large number of Chinese people towards leadership communication in Malaysia. Therefore, this study can be another source of research on the Chinese community in Malaysia.

\section{ABOUT THE AUTHORS}

Joyce Cheah Lynn-Sze is a $\mathrm{PhD}$ candidate at the School of Multimedia Technology and Communication, Universiti Utara Malaysia

Norhafezah Yusof and Mohd Khairie Ahmad are senior lecturers attached to the School of Multimedia Technology and Communication, Universiti Utara Malaysia

The authors can be contacted at: lynnsze_joyce@yahoo.com, norhafezah@ uum.edu.my and khairie@uum.edu.my 


\section{REFERENCES}

Barrett, D. J. (2011). Leadership communication. New York: McGraw-Hill Companies.

Chen, G. M., \& Chung, J. (1993). The impact of Confucianism on organizational

communication. Paper presented at the annual meeting of the 1993 SCA Convention, Nov 18-21, Miami Beach, Florida.

Cheng, C. Y. (2011). Confucian global leadership in Chinese tradition: Classical \&

contemporary. Journal of management Development, 30(7), 647-662.

Cheng, B. S., Boer, D., Chou, L. F. Huang, M. P., Yoneyama, S., Shim, D., Sun, J. M., Lin, T.

T., Chou, W. J., \& Tsai, C. Y. (2013). Paternalistic leadership in four East Asian societies: Generalizability and cultural differences of the Triad Model. Journal of Cross-Cultural Psychology, XX(X), 1-9.

Cheung, C. K., \& Chan, A. C. F. (2008). Benefits of HK Chinese CEOs' Confucian and Daoist

leadership styles. Leadership and Organization Development Journal, 29(6), 474-503.

Chin, J. (2001). Malaysian Chinese politics in the $21^{\text {st }}$ century: Fear, service and marginalisation.

Asian Journal of Political Science, 9(2), 78-94.

Christopher Selvarajah \& Meyer, D. (2008). One nation, three culture:

Exploring dimensions that

relate to leadership in Malaysia. Leadership and Organization, 29(8), 693712.

Chu, G. C., Lee, J.-W., \& Kim, W.-Y. (1991). Perception of traditional values in South Korea: A

1990 Survey. Journal of Communication Arts, 12, 81-90.

Conger, J. A. (1991). Inspiring others: The language of leadership. Academy of Management

Executive, 5(1), 31-45.

Connor, J., Min, Y., \& Iyengar, R. (2013). When East meets West: A global merger between

U.S. \& Chinese companies required the development of a leadership philosophy that combines Eastern and Western cultures. $T+D, 67(4), 54$.

De Bary, W. T. (1996). Confucian Education in Premodern East Asia. In Tu Wei-ming (Eds).

Confucian Traditions in East Asian Modernity. Cambridge, Mass.: Harvard University Press.

de Man, H. (2011). Chinese philosophy as a mirror for western leaders. The Maastricht School of

Management, No. 2011/05, 1-22. 
Farh, J. L., \& Cheng, B. S. (2000). A cultural analysis of paternalistic leadership in Chinese

organization. In Li, J. T., Tsui, A. S., \& Weldon, E. (Eds). Management and Organizations in the Chinese Context. London: Mcmillan, 94-127.

Fleishman, E. A., Harris, E. F., \& Burtt, H. E. (1955). Leadership and Supervision in Industry.

Columbus, Ohio: Bureau of Educational Research, Ohio State University.

Fontaine, R., \& Richardson, S. (2003). Cross-cultural Research in Malaysia, 10(2): 75-89.

Retrieved from http://www2.ihis.aau.dk.

Fontaine, R., Richardson, S., \& Yeap, P. F. (2002). The tropical fish problem revisited: A

Malaysian perspective. Cross Cultural Management: An International Journal, 9(4), 60-70.

Freedman, A. L. (2001). The effect of government policy and institutions on Chinese overseas

acculturation: The case of Malaysia. Modern Asian Studies, 35(2), 411-440.

Gao, J. S., Arnulf, J. K., \& Kristofferson, H. (2011). Western leadership development and

Chinese managers: Exploring the need for contextualization. Scandinavian Journal of Management, 27, 55-65.

Hackman, M. Z., \& Johnson, C. E. (2009). Leadership: A communication perspective ( $5^{\text {th }} \mathrm{ed}$.).

Prospect Heights, IL: Waveland.

Hamzah, H. (2003) Mahathir The Wake-up Call, Shah Alam: Anzagain Sdn Bhd.

Han, P. C. (2013). Confucian leadership and the rising Chinese economy: Implications for developing global leadership. The Chinese Economy, 46(2), 107-127.

Hershock, P. D., \& Ames, R. T. (2006). Confucian Cultures of Authority. United States of

America: SUNY series in Asian studies development.

Hui, H., \& Tan, G. C. (1999). The moral component of effective leadership: The Chinese case. In

W. H. Mobley, M. J. Gessner, \& V. (Eds). Advances in Global Leadership. Arnold. Stamford, CT: JAI Press.

James, K., \& Lahti, K. (2011). Organizational vision and system influences on employee

inspiration and organizational performance. Creativity and Innovation Management. 20(2), 108-120.

Kennedy, J. C. (2002). Leadership in Malaysia: Traditional values, international outlook. 
Academy of Management Executive, 16(3), 15-26.

Kim, Y.S. (2011). Confucianism-based organization value \& post-merger syndrome in cross-

border M\&A: How family-system principle hinders comm. in cross-border M\&A. International Journal of Business and Management, 6(4), 49-63.

King, P. \& Zhang, W. (2014). Chinese and Western Leadership Models: A literature review.

Journal of Management Research. 6(2), 1-21.

Lang L. L., Irby, B. J., \& Brown, G. (2012). An emergent leadership model based on Confucian

virtues and East Asian leadership practices. International Journal of Educational Leadership Preparation, 7(2), 1-14.

Lakey, P. N. (2007). East meets West: Chinese leadership research. International

Communication Studies, 16(2), 126-135.

Lee Y. F. (2004). Kedinamikan kecinaan dan identiti orang Cina di Malaysia. SARI 22, 167-181.

(In Malay).

Lee Y. F. (2010). Changes in Chinese's political involvement in Malaysia. Pertanika Journal of

Social Science \& Humanities, 18(1), 11-21.

Li, T. B., \& Moreira, G. O. (2009). The influences of Confucianism and Buddhism on Chinese

business: The case of Aveiro, Portugal. Journal of Intercultural Communication, 19.

Lin, L. H., Ho, Y. L., Lin, W. H. E. (2013). Confucian and Taoist work values: An exploratory study of the Chinese Transformational Leadership behavior. Journal of Business Ethics, 113, 91-103.

Ling, W. Q., Chia, R. C., \& Fang, L. (2000). Chinese implicit leadership theory. The Journal of

Social Psychology, 140(6), 729-739.

Low, K. C. P. (2008). Father leadership- The Malaysian perspective.

Leadership \&

Organizational Management Journal. Volume 2008(1). 75-95.

Low, K. C. P. (2011). Malay Leadership Style, the Brunei perspective. Conflict Resolution \&

Negotiation Journal, 2011(1), 14-34.

Low, K. C. P., \& Ali Yusob Mohd Zain. (2012). Confucius' teaching, good leadership and

getting on top of office politics. Educational Research, 3(9), 698-705.

Low, K. C. P. (2013). Applying Bold Leadership, the Confucian Way. Educational Research, 4(1), 64-74. 
Low, K. C. P., \& Ang, S. L. (2012). Leaders who care, the Confucian perspective. International

Journal of Business and Social Research, 2(3), 99-108.

Lu, X., Jia, W., \& Heisey, D. R. (2002). Chinese communication studies:

Contexts and

comparisons. Westport, CT: Ablex.

Mason, C. L. (2009). Policy and the acculturation of the ethnic Chinese in Malaysia. Master of

Arts Thesis.

Matveev, A. \& Lvina, E. (2007). Effective transformational leadership across cultures: The role

of cross-cultural communication competence. WCA: Communication in the

$21^{\text {st }}$ century: Exploring roots, expanding visions. Brisbane, July 2007.

McDonald, P. (2011). Maoism versus Confucianism: Ideological influences on Chinese business

leaders. Journal of Management Development, 30(7), 632-646.

Merkin, R. S. (2009). Cross-cultural communication patterns: Korean \& American

Communication. Journal of Intercultural Communication, 20, 1.

Misumi, J. (1985). The behavioral sciences of leadership: An interdisciplinary Japanese

research program. Ann Arbor, MI: University of Michigan Press.

Mohd Rizal Mohd Yaakop \& Sharifah Aluya Alinda Dewi Syed Ali (2000).

Communalism and

intercultural communication.: Impacts on national governance in Malaysia.

Retrieved from http://www.bruneiresources.com/pdf/goodgov_rizal_ communalismandintercultural.pdf

Scarborough, J. (1998). Comparing Chinese and Western cultural roots: Why East is East

and...Business Horizons, 41(6), 15-24.

Sheh S. W. (2010). Confucianism and Chinese leadership. Chinese management studies, 4(3),

280-285.

Storz, M. L. (1999). Malay and Chinese values underlying the Malaysian business culture.

International Journal Intercultural Relation, 23(1), 117-131.

Stowell, J. A. (2003). The influence of Confucian values on interpersonal Communication in

South Korea, as compared to China and Japan. Intercultural Communication Studies. 12(4), 105-115.

The Chinese Culture Connection. (1987). Chinese values and the search for culture-free

dimensions of culture. Journal of Cross-Cultural Psychology, 18(2), 143-164. 
Thompson, M. (2010). Signals of virtue in Chinese Consumerism and Business. Journal of

International Business Ethics, 3(2), 71-79.

Wang, P. (2011). Hospitality leadership: A Chinese perspective. World research summit for

tourism and hospitality, Hong Kong.

Willburn, P. T, Hackman, M. Z., \& Criswell, C. (2008). Measuring organizational vision content

and articulation: Testing a comprehensive vision model and identifying implications for senior executive leaders. Leadership review, 8, 113-136.

Wong, J. \& Kong, S. H. (2014). The mainland Chinese managerial behaviors and assumptions

since the economic reform: The literature review and research proposition. Open Journal of Business and Management, 2, 24-32.

Wong, J., Wong, P. N. K., \& Li, H. (2007). An investigation of leadership styles \& relationship

cultures of Chinese and expatriate managers in multinational construction companies in Hong Kong. Construction Management and Economics, 25, 95-106.

Wong, K. C. (2001). Chinese culture and leadership. International Journal of Leadership in

Education, 4(4), 309-319.

Zarina Zawawi \& Faisal Ibrahim (2010). Debating Asian values: A case study of Malaysian

reality TV shows. Segi Review, 3(1), 34-44. 